\title{
Substitution of Civil Society in Belarus: Government-Organised Non-Governmental Organisations
}

\section{BY}

\author{
ANASTASIYA MATCHANKA*
}

Belarus, as a young state that received its full independence only in 1991, had no historical record of sovereignty except for a few months in 1918. This short period of time did little to create the foundations for a historical discourse for most Belarusians. When compared to Ukraine, the Baltic States or Poland, due to historic ties, Belarus' path is different in many respects. In terms of civil society, or civil movements, a pre-independent Belarus never had its own Sajudis, a reform movement in neighbouring Lithuania that organised the struggle for independence in the 1990s, or massive workers movement like Solidarity in Poland. Likewise, no province existed that could shape discourse like Ukraine's Galicia, a flourishing island of independent intellectual thought throughout its history.

Belarus achieved its independence without an organised struggle, unlike a majority of its neighbouring countries. In fact, Belarus is often referred to as a country that was not prepared for its own independent statehood. These considerations have major implications for the current state of civil society in the country, as well as its development. Its strong ties to its Soviet legacy shapes people's understanding of civil society, which, in turn, is a major reason why modern concepts do not resonate well among its citizens.

The available scholarly work on the weak state of civil society in Belarus gives credence to this argument. While post-communist civil societies are often considered uniformly weak and ineffective, Belarus does not have a functioning civil society (Lenzi 2002, 404). Authentic, pro-democratic non-governmental organisations appear to be small in number, marginalised and with limited influence inside the country. At the same time, state administrative resources have witnessed substantial growth. The stronger position of the state (when compared to civil society) is due, in part, to its success in developing various levers of control to authentic civil society and the established pro-government 'non-governmental organisations' (NGOs) loyal to the state. These operate without obstacles. In the authoritarian

\footnotetext{
* Anastasiya Matchanka is actively involved with civil society in Belarus, running projects to develop civic competences among youth.
} 
state that has become Belarus, NGOs are closely connected and loyal to the authorities. This alignment allows NGOs to benefit from doing their work unhindered and extend the reach and type of activities they are able to carry out. As a result, civil society is divided, or polarised, with their relation to the state serving as the decisive dividing line between them. Distortion of the concept of civil society occurs as a natural consequence of immature nations that do not have a well-defined and widely-accepted notion or understanding of civil society.

This paper endeavours to provide a closer look at the extent to which the activities of pro-democratic organisations are copied by government-backed entities and to what extent the substitution of authentic civil society with government-organised non-governmental organisations (GONGOs) takes place. While membership in GONGOs is impressive, the extent to which the efforts to present themselves as civil society organisations can partly facilitate their popularity and supplant the work of real NGOs. Under these circumstances, it is becoming harder to promote the cause of civic values. Instances of imitating the activity of pro-democratic NGOs by organisations created by the government will be discussed and analysed. This paper is mainly based on statements and interviews from practitioners and experts in the field. This provides an additional practical dimension to the research conducted. The analysis identifies substitution in three dimensions (internal, external and mixed) and considers them separately in greater detail. It should be noted, however, that this paper does not serve as comprehensive document on GONGOs and NGOs in Belarus. Rather, it should be looked at as the foundation for further research on the topic.

\section{The Operation of GONGOs in Belarus}

The existence of a significant number of GONGOs in Belarus is one of most important factors in understanding how Belarusian civil society operates and is an issue that has long been overlooked. GONGOs are organisations that require a certain degree of dependency on the state and often are created by it. Interestingly enough, a set of organisations defined as 'state associations' or 'state NGOs' exists in Belarusian law, but these are distinct. GONGOs receive substantial benefits from the state and, as such, they represent the GONGOs described here.

If one takes a closer look at GONGOs, naturally, they do not appear to be independent, as they are initiated from above, rather than from below. Apart from being created by the government, the organisations continuously align their work with that of the state. Therefore, they do not act in the name of protecting the public's interests, but often embody a mechanism for additional governmental control over society. Their decision-making process does not follow any kind of democratic principles, but is designed to implement the state's will, rather than their own. The 
Belarusian authorities reciprocate the loyalty of GONGOs through lifting obstacles which the organisations would otherwise face. Financial dependence also plays an important role, although some GONGOs are guided by the desire to receive financial support from sources other than the state.

Therefore, the main characteristics of a GONGO are the dependent mode of their creation, operation and decision-making, privileges of extended rights in comparison to other similar organisations, maintaining the role of an implementing agent of the state, rather than as an actor for civil society. The existence of this phenomenon echoes a common practice found during Soviet times when any volunteer state association that existed was, in fact, a body in support of the Communist Party. Mandatory participation in many of these 'voluntary' organisations resulted in the rejection of the very system by Soviet citizens.

The existence of pro-government organisations ensures greater control and better rule over society by the authoritarian state. These organisations can be established in different civil sectors and for different civil society groups to ensure state control (Egorov 2009, 43). In these cases, space for authentic NGOs to function is significantly limited and can be further reduced by instituting legal regulations that make it harder for NGOs to operate. In Belarus the mandatory registration of organisations, in conjunction with the criminal liability one faces for acting in the name of an unregistered organisation, serves as mechanisms that hamper the work of NGOs.

Vitali Silitski made an important distinction between pro-democratic and pro-government organisations and argued that the 'democratic' NGOs specialise in public campaigns and seminars, while pro-government organisations are mostly represented in areas such as social projects, charity and leisure activities (e.g. festivals, contests) (Silitski 2009). This is confirmed by a quick survey of the websites of two of the best known pro-government organisations - the Belarusian Republican Youth Union (BRSM in Belarusian) and Belaya Rus'. Although the total number of their members is remarkable for Belarus (they claim to have 500,000 and 138,000 members respectively), their websites are not particularly informative and mostly list leisure activities as their specialisation (e.g. organising cultural events, concerts, sporting events). ${ }^{1}$ These two organisations will be analysed further as the most obvious examples of GONGOs.

The Belarusian Republican Youth Union (BRSM) is the most well-known GONGO in Belarus. Its overall structure is comprised of other organisations, but no detailed information is publicly available. The creation of BRSM in 2002 was the result of a merger of two organisations, the Belarusian Patriotic Youth Union

\footnotetext{
1 See more at the official web site of Belarusian Republican Youth Union at http://brsm.by/ and Belaya
} Rus' at http://www.belayarus.by/ [accessed 17 December 2013]. 
and the Belarusian Union of Youth. Today BRSM brings together about 500,000 young people, ranging in age from 14 to 31 years old, and represents about 19\% of the number of young people in Belarus. These figures, however, may be distorted as several revelations make light of their recruiting techniques. There has been a certain amount of pressure on young people to join the Union over the years, and sometimes people have discovered that they were members without having ever submitted an official membership application (Polit.ru 2009).

The organisation attracts youth using financial incentives. Card-carrying members get discounts on products and services in more than one hundred retail outlets and service centres in Minsk alone. Outside Minsk, a system of discounts for BRSM members can be found at sport clubs and swimming pools as well as beauty salons, cosmetics shops, and printing and other services that are certainly appealing to most young people. The financial incentives entice many young people to join the organisation, as Belarus constantly suffers from one or another economic crisis. It does not create equal conditions with other organisations which do not have the financial benefits to incentivise membership. Lukašenka willingly pays the BRSM for its support. For instance:

...in 2011 the BRSM received 20.5 billion Belarusian roubles (about $\$ 6.6$ million). This constitutes $98 \%$ of the total of all the finance provided to youth politics in Belarus. In reality, the BRSM gets even more. On 13 January 2003, Lukashenka signed a decree which required that local BRSM branches were financed by the local authorities' budget. The government was also responsible for repairing the organisation's main office. It is obvious that the authorities created favourable conditions for the development of a strong loyal youth organisation in Belarus (Astapenia 2012).

However, information about how exactly the money is being spent remains outside the realm of public discourse as it is not disclosed. Although the website of the Ministry of Education of Belarus lists 16 organisations that receive support from the government for their activities the aim of this support and the extent to which other organisations are supported remains unclear. The real reason behind the rise of the BRSM is the government's desire to subvert independent NGOs and other civic organisations. In this way it demonstrates its intentions to gain as much control as possible over businesses, charitable funds, and particularly youth organisations - making them subject to governmental control (Lenzi 2002, 413). BRSM is a vivid example of executing such control. The organisation receives money from the state budget, though formally it has the status of a public organisation and should be on equal footing with all other public youth organisations. In addition, the regime has successfully monopolised civic interaction with a significant faction 
of Belarusian youth. This will be described at a later point.

Much less is known about another recognised GONGO, Belaya Rus'. Their emergence followed the pattern established by the BRSM. It includes former ministers, including the ex-Minister of Education and the current Vice Chairman of the Presidential Administration, Aliaksandar Radźkoŭ, members of Parliament, the rector of the Belarusian State Pedagogical University, Piotr Kucharčyk and the rector of the Belarusian State Economic University, Uladzimir Šymaŭ, in addition to numerous other governmental officials. Almost all the senior management of the organisation (3 out of 4 vice-chairmen) have worked in the House of Representatives (i.e. the lower chamber of Belarusian Parliament between 2008 and 2012) (Shemyakin 2012). Official discourse depicts Belaya Rus' as one of the leading large-scale organisations expressing the interests of all segments of the population. The website of the organisation specifies a membership of 138,000 people (as of 1 May 2013) and lists several organisational activities. However, its real function is similar to that of the BRSM, as it serves as a 'narrow channel of articulation of public interest' (Shemyakin 2012).

To sum up, GONGOs were created to complement government activities and function as state actors, enjoying extended rights in comparison to other organisations in Belarus, rather than as representatives of authentic civil society.

\section{NGOs and GONGOs: Is There a Substitution?}

Pro-government organisations operating in Belarus have their roots in their Soviet legacy. This practice was used during the Soviet Union to provide more control over society and secure its loyalty. Belarusian political scientist Chernov describes the operation of pro-government public organisations in the Soviet Union in the following way:

...almost every citizen was a member of a public organisation (e.g. a trade union, sport club and children, youth, women, veterans associations) and was working for the benefit of this organisation by participating in its meetings, electing its leadership, paying membership fees, fulfilling permanent or one-time public duties. In reality, such popular social activity, as a rule, was the result of intense mobilisation and forced recruitment, and, besides, was under the total political control of the party-state apparatus. Each segment of Soviet society was presented by a single public organisation with a hierarchical structure. Membership in it was compulsory, and, therefore universal. Authorised 'public' organisations were built into the overall system of government. They did not have autonomy and 
operated strictly at the behest of the Communist Party, which defined the specific goals and directions of their activity, controlled the decision-making process, the selection of leaders, strictly regulated community activities and held organisations financially dependent to the state (Chernov 2009).

The extent to which the features of this Soviet practice still shape today's political life and affects pro-democracy civil society in Belarus is difficult to estimate. This might be attributed to the difficulty in differentiating between the real initiatives coming from civil society and those purely simulative in character. Indeed, a distinction between NGOs and GONGOs using objective criteria is close to impossible (Egorov 2010a).

\section{State Corporatism in Belarus}

In theoretical conceptualisations of authoritarianism studies the use of officially sanctioned public organisations to restrict people's participation in political processes is referred to as state corporatism where corporatism is defined as a:

System of interest representation, in which the constituent units are organised into a limited number of singular, compulsory, non-competitive, hierarchically ordered and functionally differentiated categories, recognised or licensed (if not created) by the state and granted a deliberate representational monopoly within their respective categories in exchange for observing certain controls on their selection of leaders and articulation of demands and supports (Schmitter 1974,93).

Originally elaborated to describe the interaction between the state and economic interest groups, the model almost immediately began to be used to analyse other interested groups, such as NGOs (Cawson 1985). Under this model, the state sets strict conditions for granting organisations permission to operate. The authorities also suppress authentic civil society groups. Such dependency reduces the number of such organisations, allowing the state to monitor their activities and supervise their members. This practice is evident in Belarus through its official state policy towards NGOs and democratic civil society. Restrictions on the representation of real interests in Belarus and its various limitations can be traced along two veins of thought for maintaining state control. Firstly, the neutralisation, or limitation of opportunities for public activities of independent NGOs, with the most advanced NGOs being excluded entirely from operating (Chernov 2007, 15). This is made possible through impediments to registration and limited possibilities inside the country to advocate civil society causes (due to restrictions on freedom of speech 
and assembly). Secondly, the creation of GONGOs and other public society organisations by the government that replace authentic NGOs and promote state policies in their respective segments of society (Chernov 2007, 5).

As a result of this system, two risks become apparent due to the undeveloped political culture. First of all, the state (in relation to a weaker civil society) starts the process of incorporating and substituting real mechanisms for people to represent their interests. Secondly, it can distort the perception of the public towards civil society, in the absence of other models of a civil society to refer to. It is especially alarming under the current political regime in Belarus, when the strength of the state is supported and reinforced by a weak political culture of participation. The processes of centralisation of state power and consolidation of the authoritarian nature of Lukašenka's regime, has led to a significant decline in civil society structures.

A considerable number of public organisations in Belarus do not just work closely with government agencies, but are incorporated into them and depend almost entirely on the will of the political elite (Sidarovič 2007, 80). As a result, the sector of society originally meant to be an arena for civil society is being intensely incorporated into the state, creating a 'hybrid state-public sector' (Sidarovič 2007, 75). One of the consequences of this blend of the state and civil society is seen in data from two opinion polls from 2005 and 2010, which give light to society's eroding perception of NGOs. Three important trends can be outlined ${ }^{2}$ :

A lack of understanding of NGOs role and function and an absence of knowledge about the problems faced by civil society. The public does not see the need to protect public interests through participating in NGOs and supports the introduction of stricter controls over the activity of NGOs (Čavusaŭ 2005, 3-5).

There is a lack of knowledge about NGOs. In 2005 only $30.7 \%$ had a formed an attitude (either positive or negative) towards NGOs, while the rest (69.3\%) did not explicitly relate to the role of civic, or non-governmental organisations in Belarus (Čavusaŭ 2005, 3). Another study from 2010 shows that $44 \%$ of respondents said they did not know what an NGO is (Assembly of Pro-Democratic NGOs and Eastern Europe Studies Centre 2010, 2). There are no prominent organisations independent from the government in the Belarusian public sector. In the 2010 survey most respondents to the open-ended questions named only the BRSM, Belaya Rus' and the Consumer Rights Protection Society, whilst references to names of

2 The outlined trends are based on the analysis of the following reports: (1) Jury Čavusaŭ 'Hramadskija abjadnańni: ich rolia ŭ sučasnym hramadstvie. Analityčnaja zapiska pa vynikach nacyjanalnacha sacyjalagičnaha apytańnia', Minsk, September 2005. (2) Assembly of Pro-Democratic NGOs and Eastern Europe Studies Centre, 'Non-governmental organisations: their role in the modern Belarusian society, Briefing note on the results of a national poll', Minsk, 2010. 
pro-democratic NGOs were negligible (Assembly of Pro-Democratic NGOs and Eastern Europe Studies Centre 2010, 6).

There was difficulty in defining civil society as an agent of anything separate from the state. People's perceptions of NGOs transmit stereotypical perceptions of NGOs in the framework of Soviet collective-style thinking (often this stereotype is sanctioned by the state) (Čavusaŭ 2005, 7). The public's poor state of information awareness legitimises state policy in regard to NGOs and reinforces the existing model of relations between state and society (Assembly of Pro-Democratic NGOs and Eastern Europe Studies Centre 2010, 10). The 'voluntary' sector is either not viewed as part of 'civil society' (the 'voluntary' sector is understood as organisations loyal to the state), or 'civil society' is only viewed as 'democratic civil society' (with pro-government organisations excluded from it). The mixture of 'democratic' and 'pro-government' factions in a single civil community is confusing for the public. There is a sense of difference between pro-government, democratic political and democratic neutral organisations among the population, but it cannot transmit this distinction to defining NGOs, which seem abstract to them (Čavusaŭ 2005,13 ). Another example from the 2010 study shows that about $40 \%$ of people surveyed said that NGOs should be of assistance to the state and act as a state agent (Assembly of Pro-Democratic NGOs and Eastern Europe Studies Centre 2010, 4). It is fair to state that this is typical of people's understanding of NGOs in Belarus.

The data illustrates the increasing role of GONGOs in the Belarusian political model, promoting a distorted idea of civil society. NGOs are defined, when it comes to civil society activities (as GONGOs are typically organisations dedicated to sports or leisure time activities, by the dichotomy of their degree of dependency/ independency on the state. Belarus' immature civil society also demonstrates that patterns of participation have not yet been fixed. Public opinion about civil society and the role of the civil sector can be formed under the influence of all the features of a hybrid civil society. Thus, Belarus is reviving the old corporatist system of interest groups in the field of state-civil society relations with one significant difference - it is 'no longer totalitarian (post-totalitarian) but classic authoritarian corporatism' (Chernov 2007, 4).

\section{State Relations with GONGOs and NGOs}

Civil society as a public sphere of citizens engagement, and a way for individuals to organise themselves to voice their interests in different areas, is often considered to be an agent of society that is independent of the state. The current classical understanding of civil society assigns it to a 'third sector', as opposed to the state or market (Corry 2010, 11). However, in Belarus the rules of the game 
for civil society are drawn up almost exclusively by the state. Thus the state indirectly influences civil society while depriving the latter of such an opportunity. As closer ties with the government can bring tangible benefits for organisations, the extent to which they are tied to, or dependent on the government, is important. A variety of patterns of relations between the state and GONGOs and NGOs should be reviewed emphasised.

While the state has various instruments it can use, for good or ill, to influence the health of the NGO sector, relations between civil society and government can be characterised in different ways: non-interventionist, active encouragement, partnership, co-option or control (Clark 1993, 8). For individual NGOs the most favourable policy setting is when legal restrictions are minimised and they have complete freedom to receive funds from whomsoever they choose, to speak out and to associate freely (Clark 1993, 9). Belarus' NGOs do not enjoy these rights, as the state has a control-based relationship with society. The state executes control through a pervasive ideology, the dominance of media, repression of political activists, non-acceptance and suppression of any form of civil discontent. Numerous obstacles for the operation of NGOs, including the infamous article 193.1 of the Criminal Code of Belarus, exist. Simply put, this article stipulates that activities of unregistered organisations are subject to criminal liability.

This control was gradually consolidated throughout Lukašenka's rule. Starting in 1995, the President strengthened his regime by gradually sweeping away opponents, or anyone that could compete with the President in the political arena. He concentrated all power in his hands by bringing the Parliament, court system and security forces under his direct control. The rigour with which the measures were introduced led to the seizure of the judiciary, the lower and upper houses of parliament, which in effect gave the president carte blanche for nominating and removing people to and from key positions in these institutions. The strategy of corporatism employed in an authoritarian state is in line with control-based relations between the state and NGOs. It is characterised by the existence of limitations in the registration process and the creation of GONGOs, to attempt to pre-empt the creation of truly independent grassroots NGOs and attract funding from foreign states and donors (Heurlin 2010, 222).

The state cooperates willingly with GONGOs, rather than with NGOs, for easier control of their activities and financial flows. As the state is not always able to satisfy the needs of the GONGOs it had created, international funds open up additional opportunities for such organisations (Iryna Žychar, Interview \#3, 2013). The creation of GONGOs extends possibilities for their government-controlled operators and, in particular, provides access to these external funds. The trend of financial flows going from government to civil society should be taken into 
consideration as an additional factor when analysing the state's intention to use GONGOs as grantees in international projects. There has been a steady increase in donor assistance to civil society in Belarus. The EU and the United States have increased financial assistance for the 'Governance and Civil Society' sector after the 2010 presidential election and repression that subsequently followed. The EU increased its aid by a magnitude of 1.5 and the United States by $12 \%$. This trend was clearly observable already in 2010, when donors such as the United States, Germany, Sweden and France significantly reduced the distribution of aid through government institutions and appealed to civil society instead. In 2006, for example, twice the amount given in 2010 was allocated to the public administration than was provided to civil society. In 2011 eleven times more funding was allocated to civil society compared to the amount of funding for the government (Shylo and Egorov 2013, 16).

Another reason for the state's more favourable attitude towards GONGOs, as opposed to NGOs, is that it gives the state a chance to shift some of its own workload from the state level to their sponsored organisations and still be able to yield benefits from the work done. Reference to GONGOs as 'agents hired by the state' is a fairly accurate assessment of these organisations (Iryna Žychar, Interview \#3, 2013). Choosing the 'easy road', the state cooperates with GONGOs, which are its own creation, as a tool of keeping real NGOs out of the real decision-making process, or having a voice in the dialogue surrounding important issues. Having said that, it would undoubtedly be wrong to think that every act of cooperation with the state makes an organisation pro-government. The extent of independence that an organisation is ready to maintain in exchange for said cooperation is pivotal. For some organisations state cooperation, and even support from the state, appears to be a leading principle when they are considering the work they wish to conduct. They are ready to exchange their own independence in order to merely exist and continue on with their work. This mainly refers to those organisations working in the area that necessitates vital government input (e.g. working with the disabled or socially marginalised groups) (Taciana Paševalava, Interview \#1, 2013 and Jury Čavusaŭ, Interview \#6, 2013).

The differing levels of dependency of organisations on the state make the line of demarcation between organisations cooperating with the government and a pro-governmental GONGO extremely thin. At the same time, limited cooperation in an authoritarian state, like Belarus, is possible even with democratically oriented NGOs who can be an effective contact and partner for the government without having their independence compromised. The interests of the state in its interactions with the civil sector can at times converge in order to ensure the non-appearance of a group being seen as an alternative to the state. In case they do appear, they are eliminated through marginalisation, or replaced by a pro-government entity (An- 
drei Egorov, Interview \#5, 2013). The evidence suggests cooperation is possible even for unregistered organisations. However, the success of this cooperation often proves volatile and depends on the area of cooperation (Taciana Paševalava, Interview \#1, 2013 and Anna Herasimava, Interview \#4, 2013). The state allows for some topics to be open to real cooperation (e.g. the environment), but also denies others that encroach on its own mandate such as, for example, electoral reform. At the same time this cooperation is fragile and does not eliminate the same problems organisations had prior. Nor does it ease the burden of operating under unfriendly conditions. Thus, the same organisation may successfully cooperate with the state on one issue and have the completely opposite result on another matter (Andrei Egorov, Interview \#5, 2013). A vivid example can be drawn from ecological NGOs when a successful campaign on draining swamps was followed by a campaign against a nuclear power plant which encountered serious pushback from the authorities and zero state cooperation (Taciana Paševalava, Interview \#1, 2013).

Some NGOs choose the strategy of leaning towards the "nomenclature dialogue' in their relations with the state, often for pragmatic rather than ideological considerations. 'Nomenclature dialogue' is referred to as the

...development of a reform programme in specific directions and its implementation with the assistance of the authorities which might also lead to abandoning some of the political demands for the sake of evolutionary reforms (EuroBelarus 2013).

However, positive outcomes and, therefore, the level of desired cooperation can be impeded by the presence of the 'political aspect' in the activity of such organisations. While there are organisations that solely deal with providing services and, thus, avoid the politicisation of their activities (and according to some experts, the number of such organisations is growing (Taciana Paševalava, Interview \#1, 2013), there are others trying to influence or change government policies and engage in solving various problems. In Belarus this is perceived by the regime as 'politics'. In sum, several conditions have to be met in terms of cooperation between organisations and the state: a) there are only certain areas in which cooperation is possible b) the activity of the organisation should not be perceived as a threat to the regime and c) chances for cooperation is higher in instances where the issue is not acutely political.

\section{Is There a Substitution?}

The concept of substitution exists in the theoretical literature in connection with failed states when a state can no longer implement its role as a provider to the public of necessary services and civil society takes over (Posner 2004, 237). This 
approach, however, assumes the state is 'good' by default and relations between the state and civil society are either complementary or substitutionary. As government efficacy deteriorates, informal social groups become substitutes for the state (Narayan 1999, 16). However, when a government is strong and repressive, the extent it is able to implement policies can sufficiently limit the meaningful existence of civil society. After analysing the theoretical considerations of various aspects of GONGO operations in Belarus, below is presented a further analysis of cases of substitution.

As described, Belarus employs control-based relations with civil society and has revived a state corporatist model. In this section we will consider the most recent evidence in Belarus when GONGOs were acting as representatives of pro-democratic NGOs or had the intention to be perceived as such, which will be analysed as a tool to identify instances of substitution. These cases are grouped into three categories. These include instances of the creation of official organisations and structures that are counterbalancing the activity of independent pro-democratic NGOs; cases when GONGOs, or their representatives participate in providing evaluations of civil society in Belarus; and reports on instances when GONGOs received funding intended for pro-democratic NGOs, all of which will be presented below.

\section{Creation of 'Official' Organisations to Counterbalance Democratically Oriented NGOs}

Often authoritarian states create organisations to counterbalance and 'mirror' the activity of pro-democratic NGOs. Formal NGOs that exist only on paper were also created during the Soviet Union, so the phenomenon is not totally new. One of the earliest examples of simulative organisations in the history of independent Belarus occurred back in the early 1990s, when aid programmes for fighting the consequences of Chernobyl were opened by Belarusian NGOs. Funding was distributed directly to NGOs, bypassing the government. After 1994 GONGOs were established to take the money devoted to fighting the consequences of Chernobyl and aid programmes were 'governmentalised' (Matskevich 2012, 45). The same followed with programmes involving the competence of structures of (e.g. border guard equipment, fighting trafficking in people and drugs). The government created sham organisations which existed only on paper and were composed of state officials (Matskevich 2012, 45).

Such examples have also occurred in other countries. In Slovakia, for example, during the Meciar times in the mid-1990s, civil society was seen as a threat and GONGOs were commonly used to ensure better governmental control over civil society. Such was the case with youth organisations, where the independent Youth 
Council of Slovakia was confronted by the Slovak Youth Congress, which was comprised of representatives of the youth structures of the ruling coalition under Meciar. A similar situation involved the Slovak Syndicate of Journalists and the Association of Slovak Journalists (Forbrig 2004, 260). This trend (like the one described above), is repeating itself currently in Belarus. The names of the organisations are often strikingly similar, making it even harder to distinguish among them. Despite having certain privileges, like access to state funding and the absence of impediments to their activity. These organisations subordinate their agenda to the state and follow the general ideology of the state. One of the most significant examples of organisations that mirror the activity of NGOs are those organisations devoted to young people, including the BRSM, the National Council of Youth and the children's organisation 'Rada'.

The national Council of Youth and children's organisation 'Rada' served as an umbrella organisation, uniting both registered and unregistered associations under a platform for dialogue with a good balance of representation from various groups. The BRSM, after its creation in 2002, aspired for membership in Rada. Due to a vote during one of its meetings, Rada rejected the application to avoid the monopolisation and governmentalisation of activities pertaining to the nation's youth. Following that decision, Rada and its members encountered pressure and criticism. The President himself, during his annual address in 2003, spoke on the growing importance of the nation's youth and the importance of the state in developing the potential of young people:

A significant role has to be played by the Belarusian Republican Youth Union. It should reveal itself as a genuine organiser, leader of the youth movement in the country. Instead, BRYU, right after its creation fell under the umbrella of the so-called Rada. A huge organisation went under some kind of worn-through umbrella... (Poslanie Prezidenta 2003).

Prior to that, Rada had some cooperation and dialogue with the state, however since 2003 communication has stopped. From 2003 until 2006 the state actively exerted pressure on the members of Rada until they were either abolished or had withdrawn their membership. Of the 30 organisations comprising Rada, around only seven members were left by 2006 (Belorusy $i$ Rynokaa 2006). A lawsuit against Rada was then filed. Its accounts were frozen, and the organisation was officially closed in 2006 after its registration was recalled. The interest of the state was clearly the monopolisation of society's youth policy. To do this it ostracised and allowed one of the most well-known youth organisations of the time to closedown.

After the elimination of Rada, the BRSM under the close patronage of the state, 
began establishing itself as the leading organisation in the youth sector domestically and abroad. Its efforts abroad included filing an application for membership with the European Youth Forum three times, along with several attempts to deprive Rada of its membership status. As of now the BRSM participates in all state programmes for youth and educational policy, and enjoys considerable state support with Presidential decrees issued to formalise their position. Despite the diversity of other youth organisations, the BRSM is brought to the fore as it enjoys the state's full support. BRSM was elevated to the rank of a leading organisation, overshadowing the activity of other organisations with similar target groups.

The legal operation of GONGOs can be ensured through the potential criminalisation of organisations which might otherwise be competitors. With the requirement of registration (the granting of which is fully in the government's hands) and space for the operation of loyal organisations is rapidly expanding at the expense of NGOs (as shown by the two organisations in question). Thus, the state-public sector is formed by granting preferences to organisations loyal to the government (Sidarovič 2007, 79).

In 2003 the Belarusian Committee of Youth Organisations (BCYO) was created which, (along with the BRSM), was supposed to copy the activities of Rada and other organisations working in the youth sphere. Currently, BCYO consists of 39 youth and children's organisations, with the task of 'improving relations between public organisations and the government' (Monitoring obshestvennogo mnenia $\mathrm{V}$ Belarusi 2010). However, BCYO exists only on paper. It does not have a website, and available information about its activities is limited. The committee members do not know its structure nor its activities. They were only invited to the first congress. Some of them did not give consent to their membership (Altenatyŭnaja moladzievaja platforma 2011).

Another example of the existence of two sets of organisations is the Union of Writers. The democratic aspirations and intractability of its leadership deprived the organisation of property. The authorities initiated a split in the Union and supported the creation of a new Union of Writers of Belarus (UWB) in 2005, which was loyal to the state (Matskevich 2012, 46). The latter organisation is led by the Chairman of the Committee on Foreign Affairs and the National Security Council of the upper chamber of the Belarusian Parliament, Mikalaj Čarhiniec. UWB was intended to fulfil the states needs in the artistic and literary sphere and enjoys considerable state support. Members of the UWB enjoy full support from the state (Sidarovic 2007, 80). The same is true with the Union of Polish minorities, where two unions exist, one supported by the government and the other one in opposition.

Other cases include the Belarusian Journalist Association (pro-democratic) and 
its governmental counterparts - the Belarusian Union of Journalists, the Belarusian Union of Women (pro-government) and the Belarusian organisation of Working Women (pro-democratic), 'Green Network' (pro-democratic) and the pro-government organisation 'Ecological Initiative', as well as official and pro-democratic (i.e. independent) trade unions. These are some of the most well-known and commonly referred to examples, but the list is not exhaustive. The existence of such GONGOs creates an imitation of public dialogue in the country. In case the authorities ever need to show the democratic nature of the state and improve society's perception of its democratic state, it will use GONGO organisations, whilst eradicating uncontrolled NGOs from the public sphere (Egorov 2011, 43).

The support that GONGOs enjoy from the state often comes at the expense of real NGOs. In return GONGOs need to execute the state's will. This becomes evident, for example, during election campaigns when GONGOs play a leading role. The widespread practice of nominating electoral commission members and observers from such structures lends credence to this claim. As the report on the campaigns leading up to elections 'Human Rights Defenders for Free Elections' from 2010 shows, the vast majority of domestic observers were representatives of pro-government associations and political parties loyal to the authorities:

The majority of observers $(20,715$ out of 39,619$)$ represented the five largest GONGOs: Belaya Rus', the Belarusian Republican Youth Union, the Belarusian Women's Union, the Belarusian Public Association of Veterans and the Federation of Trade Unions of Belarus ... their aim was to confront observers from pro-democratic organisations and journalists (Doklad po rezultatam nezavisimogo nabludenia 2011).

The BYCO, along with conducting election observations and providing nominees for election committees, holds opinion polls. The results of which usually mirror official election results. Interestingly enough, only two Belarusian organisations were allowed to conduct exit polls during the latest Presidential elections (2010) - the BCYO and the analytical centre EcooM. The latter was created with direct support of the Administration of the President of Belarus and its previous exit polls caused an ambiguous reaction during the 2004 referendum and the 2006 elections. The results of these exit polls were opposite to those obtained by the Baltic branch of Gallup and other independent observers such as UA REGNUM. This provides doubts as to the methodology of EcooM.

\section{Structures Built to Imitate a Dialogue with Civil Society}


In addition to creating organisations which mirror the activity of non-governmental organisation, instances of civil society structures providing a facade of cooperation between the state and civil society also are known to occur. One of the first examples refers to a period when the OSCE Advisory and Monitoring Group (AMG) office in Minsk was opened following the closure of the Soros Foundation in 1997. As described by Lenzi:

The office was opened with the intent of assisting the Belarusian authorities and civil society in the development of democratic institutions of a European standard and to monitor the compliance of Belarus with OSCE commitments. After protracted negotiations, the AMG office was finally allowed to open in August 1998. Although the mission could have been an effective mediator between the Presidential Administration and civil society structures, its hands have been tied by the regime's disregard for any meaningful dialogue. Lukashenko withdrew from the process and opened a sham political dialogue with carefully selected pro-regime NGOs $(2002,412)$.

The Belarusian authorities involved various organisations as civil society representatives, when in fact the area of their work was not relevant to the agenda. This was the regime's version of demonstrating an alleged dialogue between civil society and the state. The GONGOs, thus demonstrated their loyalty and did not provide critical remarks (Matskevich 2012, 47). Thus, their presence provided additional legitimisation to the decisions of the President and a positive evaluation of the status quo in Belarus. However, it could not be considered a guarantee of true civic dialogue. The environment was not conducive to involving all existing civil society organisations. In 2009, the Public Advisory Council (PAC) in the Administration of the President of the Republic of Belarus was created with the objective to:

... discuss issues of current importance on the development of the state and society, develop proposals for the active involvement of Belarus in global processes, improvement of the directions of socio-economic and political development of the country (TUT.by 2009a).

Not only GONGOs, but also representatives of pro-democratic NGOs were invited. PAC was designed to regularly meet and discuss issues that were then to be communicated to decision-makers. However, no explicit feedback mechanism was put in place. Whether the views of PAC members were actually taken into account remains unclear (Novaya Evropa 2009). Although a variety of opinions exist on how successful the PAC was, a few important points on its operation and activities have to be taken into account. 
The Head of the Presidential Administration, Uladzimir Makiej, created PAC. All of its representatives were personally selected by Makiej, without any public discussion. The agenda was also formed mostly by the Head of the Presidential Administration (Jaraslaŭ Bekiš, Interview \#7, 2013). The creation of the Council coincided with the announcement of the Eastern Partnership programme, where Belarusian civil society was to have a voice at an international level in the framework of the established Civil Society Forum of the Eastern Partnership. In 2010 Uladzimir Makiej expressed the readiness of the PAC of the Presidential Administration to represent Belarus at the Civil Society Forum of the Eastern Partnership (Belapan 2010). Interestingly enough, Makiej expressed his intention to do precisely this and pursued it vigorously despite that the fact that the National Platform of the Civil Society Forum had already been created. The selection procedure was done, the delegation members were selected, and as such PAC formally could not aspire to participate (Egorov 2010b). The reasoning behind the validity of the claim was that PAC 'is a meaningful structure in Belarusian society and its position is being taken into consideration in decision making' (Novaya Evropa 2010). Such statements should not be accepted at face value, as no explicitly transparent or democratic mechanism existed to demonstrate these claims.

Under the scheme of PAC's participation in the Civil Society Forum, the Presidential Administration defined the composition of the delegation (Matskevich 2012, 51). It was an attempt to control civil society not only 'from inside' the country, but also from the outside, through its aspirations to represent civil society externally. Experts confirmed its imitative character at public hearings initiated by NGOs to discuss the place and purpose of PAC (Egorov 2010b). The statement of PAC on its participation in the Civil Society Forum preceded the creation of civil society platforms in the framework of the OSCE project 'Development of the capacities for cooperation between government and civil society organisations'. Jury Zahumiennaŭ and his organisation, the Support Centre for Associations and Foundations (SCAF) initiated the creation of twelve platforms (e.g. education, culture, human rights, social security and business). The completion of this process was set to be confirmed through the creation of a nationwide NGO platform under the patronage of PAC (Egorov 2010a).

Yet, pro-democratic NGOs had already created a nationwide NGO platform uniting various organisations in the framework of the National Platform of the Eastern Partnership Civil Society Forum (NP CSF). Thus, the structure proposed by Zahumiennaŭ could not be distinguished from the one already created. This had resembled an attempt to create a national platform of organisations to counterbalance the existing state line, with the only distinction between them being that it was composed of non-government controlled entities. The members of the NP CSF stated there are not 'enough reasons to believe that the above [...] structures 
established in recent months are truly focused on an equal dialogue with civil society' (Eastern Partnership Civil Society Forum 2010). The mechanisms of existing platforms for dialogue and NP CSF were not taken into consideration. The process was also characterised by a 'lack of publicity and transparent procedures on the side of the new platform organisers with regard to the selection of participants, [and] certain public statements do not correspond with real activities' (Statement by the Members of the National Platform of the Eastern Partnership Civil Society Forum 2010).

All three processes (the creation of PAC, alternative platforms and aspirations to take part in the Civil Society Forum of the Eastern Partnership), confirmed the state's attempt to demonstrate its reconciliation with civil society inside the country. Still, the regime also replaced civil society structures with identical ones tailored to this aim. After this process raised public condemnation inside and outside the country, the structures were deactivated. PAC was dissolved in 2011, following a lack of meetings for over a year. After its termination, experts agreed that it was of little value to the authorities and the opposition (Dunaeva 2011). Thus, proving its initial function of being created for the purpose of imitating a state-civil society dialogue. The NP SCF in the Eastern Partnership continued without other organisations joining it.

\section{GONGO Participation in the Evaluation of Civil Society by International Organisations}

Jury Zahumiennaŭ and his organisation SCAF is associated with yet another case involving GONGOs. This case involves the preparation of a report based on the CIVICUS index on civil society methodology that was done within the framework of a project supported by the Organisation of Security and Cooperation in Europe. CIVICUS is an international alliance and represents an influential network of organisations at the local, national, regional and international levels, thus spanning a broad spectrum of civil society groups and organisations worldwide. The CIVICUS index is a valuable tool in helping to evaluate civil society in over 75 countries. Its findings are disseminated to country experts and stakeholders, who use it for assessing the situation in a country. The preparation of the stability index report on Belarus under the auspices of CIVICUS was coordinated by Zahumiennaŭ, though since its creation, several flaws have been identified in the process of its preparation.

First of all, it is not clear why the choice was made to use SCAF and Juri Zahumiennaŭ. The Belarusian public has rarely mentioned this organisation, nor does it appear to have much knowledge about it. The official website of the organisation 
looks modest and does not provide clear information about the organisation: No information could be found on the staff and concrete activities, some web pages are outdated referring to the fifteen year old news. It can be understood from the English version of the website that the scope of their activities range from facilitating the removal of anti-personnel mines to strengthening civil society (Bian'ko 2009). Secondly, during the course of the research project, the NGOs which participated in it withdrew from the process as the methodology used did not prove to be accurately designed for assessing the reality in Belarus (Taciana Paševalava, Interview \#1, 2013). An analysis of what the appropriate methodology should have been was assessed by the Belarusian Institute for Strategic Studies and Centre for European Transformation. They concluded that the findings did not reflect the results from the measurements of the index (Shelest, Vodolazhnskaya and Silitski 2010). The report indicated the need to create alternative platforms and an NGO platform to counterbalance the already existing platforms of organisations. However the authors of the assessment stated that

... actions on the formation of thematic platforms and the creation of a national platform of civil society are not the result of the research of the Civil Society Index. The initiative on the creation of such platforms has not passed through the necessary discussion and analysis (Shelest, Vodolazhnskaya and Silitski 2010).

As a reaction, CIVICUS issued an official apology for the confusion and explained that its involvement with SCAF 'CIVICUS had not been able to ascertain ... whether there would be sufficient Civil Society Index findings available to achieve the two key objectives' (CIVICUS 2010). The reference to CIVICUS, being as it is recognised as a credible organisation for conducting such research, emphasises that the report was meant to be distributed not only in Belarus, but also internationally. That said, Zahumiennaŭ had intended on cooperating, provided that SCAF benefitted from this cooperation, as did the state, as SCAF was acting in its interests.

Another trend refers to a recent situation with the United Nations Universal Periodic Review (UPR). The UPR presents a unique mechanism of the UN Human Rights Council for verifying the compliance of member states with human rights standards every four and half years. It is conducted with the involvement of both the state in question and the country's NGOs. The UN office has cooperated with the Belarusian Ministry of Foreign Affairs on the second process of review for the UPR to be held in 2015. Although the UN office is supposed to hold consultations with NGOs, unregistered organisations were not invited to the recent consultations. In addition, not all leading human rights organisations participated (Anna Herasimava, Interview \#4, 2013). The fact that the UN 
refused to cooperate with the organisations that the government did not see as acceptable subverts its own democratic principles (Anna Herasimava, Interview $\# 4,2013)$. This inconsistency often creates situations where the UN office publicly declares its unwillingness to cooperate with unregistered organisations. However at the same time, the UN demands freedom of association, including the lifting of bans on unregistered organisations (Centr pravovoi transformacii 2013).

The involvement of GONGOs in the official meetings of the UPR demonstrates an attempt to simulate the process of interaction between state and civil society, while keeping real NGOs out. The state sanctions the participation of GONGOs in exchange for their role in confirming that civil society agrees with the government. Usually they have no remarks as to the substance of the issue(s) under discussion. This carries the risk of creating an unobjective presentation of the human rights situation in the country. The outcome of the process will only be available in 2015, when the next review will be published. The concern in the short-term remains that by positioning themselves as the sole representatives of civil society, GONGOs restrict the participation of pro-democratic human rights organisations, legitimising the process.

\section{Funding of GONGOs Through the Programmes Tailored for Support of NGOs}

In the surreal world that is Belarus, issues related to funding, in general, are a difficult area to analyse. Many international organisations working with the Belarusian regime do not operate openly. The information available about their activities is limited. This stems from the requirement to register international projects inside the country, which is the only legal way for international aid organisations to operate, irrespective of its purpose. The odds of successful registration of projects for NGOs are extremely low. So an NGO must consider the dilemma of either having its request rejected to operate with the funds they have received or face refusal and become involved in lengthy bureaucratic procedures with a high likelihood of a decidedly negative outcome. Most NGOs choose the latter and decide not to register their projects in the first place. Any projects implemented without proper authorisation and registration potentially makes an organisation an illegal entity not authorised to the financial support it is receiving. In this regard, avoiding the potential exposure of local grantees is justification enough not to reveal information about recipients.

While certain donor programmes deal with the state and its actors, aid projects intended for the development of civil society, NGOs, or non-state actors 
are also available. Pro-democratic organisations in Belarus are deprived of state financial support and are highly dependent on external funding. The allocation of international aid is increasingly important for the operation of civil society. At the same time, the economic situation has deteriorated year after year. The authorities constantly pursue financial opportunities that can sustain the status quo inside the country. Following this line of logic, Lukašenka publicly motivated BRYU to reach self-sufficiency and obtain financial resources from sources other than the state budget. As a result, BRYU stated their plans to receive European funds (TUT.by 2009b). While there is no publicly available information about the sources of funding for BRYU, it has confirmed cooperation with such organisations as the Council of Europe, European Youth Forum, as well as various Youth Unions in Russia and the CIS. This does not itself prove their cooperation with other NGO programmes, but the absence of reliable information poses certain challenges in this respect.

The necessity of acquiring additional sources for financial infusions which has been encouraged by the government, in addition to the increased financial support provided to civil society by international donors since 2010 , is more than enough motivation for GONGOs to draw financial resources from wherever possible. In addition, the funding is usually not allocated to well-known GONGOs but rather to organisations that work in cooperation with BRYU or are part of its structure and less well known (Taciana Paševalava, Interview \#1, 2013). In this case, detection of such GONGOs becomes extremely problematic and depends on whether there is someone willing to disclose it. In general, there are many implications that funding is making its way to GONGOs, however, they are rarely proven or supported with facts or confirmed by real cases.

While there are GONGOs that apply for money designated for NGOs, the important implications for donors have to be taken into account. On the one hand, it becomes difficult for donors to differentiate between GONGOs and NGOs currently in Belarus, where two parallel sets of organisations exist (Iryna Žychar, Interview \#3, 2013). On the other hand, some donors consciously grant money to pro-government organisations (Anna Herasimava, Interview \#4, 2013). The reason for this behaviour is an apparent attempt by donors to normalise relations with the Belarusian government and try different approaches towards cooperation (Anna Herasimava, Interview \#4, 2013). The idea is that by cooperating with the government, and by at least partially playing by its rules, their work will bring future dividends and help influence the situation to the benefit of the people. The desire to keep good relations with the state also explains this tendency. One such example of foreign aid being allocated to pro-government organisations is the European Union Non-State Actors and Local Authorities in Development (NSA LA) programme. 
The programme, introduced in 2007, is oriented towards strengthening capacity of civil society organisations and local authorities.

A new tendency has emerged with regards to the funding mechanism under this programme since 2013 - namely, the competition requirements have changed. Now there is a demand that all partners in the project must be registered. If the applicant acts as an international organisation, it must have at least one registered partner in Belarus. Interestingly, the European Commission's official position remains the same, but its practices clearly paint a different picture. Before this change, a formal partnership was sufficient for an application for European grants. At that point registration was not an obligatory condition. Yet now, since there are problems with organisation registration, many of them do not fit these requirements. The criteria set forth excludes the programme's main stakeholders due to their support for democracy and human rights (Anna Herasimava, Interview \#4, 2013). It has become increasingly difficult for projects of 'undesirable' organisations to be supported by the European Commission programme for non-state actors.

UN programmes have also reportedly shifted their focus from real NGOs to GONGOs (Taciana Paševalava, Interview \#1, 2013 and Jaraslaŭ Bekišs, Interview \#7, 2013). According to programme guidelines, NGOs have to benefit from the grants. However, as of 2000, the focus has shifted towards working with GONGOs (Taciana Paševalava, Interview \#1, 2013). Thus, the decision-making of the Global Economic Fund is tied to the ministries, as some of the ministerial representatives are included in the Council. In this way these members of the Belarusian government give grants to GONGOs (Jaraslaŭ Bekiš, Interview \#7, 2013). The Council of Europe supports GONGOs engaged in ecological activity (Jury Čavusaŭ, Interview \#6, 2013), even allocating grants to an organisation which has existed for only one month. Despite this organisation being almost completely unknown, it received funding to the detriment of the pro-democratic alliance of ecological NGOs 'Green Network' (Andrei Egorov, Interview \#5, 2013). While more research is needed to investigate the cases mentioned, one can state the existence of a tendency on the part of international donors to support organisations considered to be GONGOs.

\section{Conclusion}

The uncontested realm of politics in Belarus excludes civil society actors from taking part in the decision-making process. In this way the state monopolises politics and diminishes the space available for the presentation of alternative views. The conditions necessary for the formation of a robust civil society significantly deteriorate as freedom of expression and assembly remain under constant challenge. The shrinking space for NGOs to work legally is alarming. The difficulty 
and selective nature of registering an $\mathrm{NGO}$, the criminalisation of the activities of unregistered organisations, the marginalisation of strong NGOs, fundraising obstacles and the creation of government controlled GONGOs have all diminish the legal space for the existence of alternative civil society organisations.

The conditions under which civil society must operate are shaped by a control-based approach of the state towards these organisations. Control manifests itself in the incorporation of civil society by the establishment of GONGOs, whose membership exceeds the membership of any pro-democratic NGOs. The state corporatism model, as expressed in Belarus, provides the possibility for the state to inhibit the growth of NGOs and marginalise strong (or more well known) NGOs. To do this, it creates GONGOs that supplant the work of civil society organisations. These are given preferential treatment and the full support of the government. Close analysis identified that substitution was indeed occurring. Substitution is occurring through the growing number of GONGOs operating in Belarus, organisations which often mirror or mimic the activity of existing NGOs.

The grounds for substitution exist. However, in the cases mentioned, such attempts were characterised by their essentially restrained nature. The third aspect analysed a mix of the states attempts at external and internal substitutions, which involved funding GONGOs for programmes that are tailored to support civil society and NGOs. A clear tendency of providing grants to GONGOs is outlined in this article. One can state that the formation of an environment conducive for the substitution of pro-democratic NGOs has been established.

Under the conditions of a repressive and consolidated authoritarian regime, reinforced by a weak civil society, substitution leads to distorted perceptions of civil society and NGOs. Existing sociological research shows that GONGOs are better known than authentic democratic NGOs. Apathy and a lack of interest in the activities of NGOs reinforce this argument. Coupled with the restrictive environment for the operation of civil society by the government, GONGOs are perceived as 'authentic' NGOs. Appropriate grounds for a comprehensive understanding of the role of civil society and NGOs needs to be laid down. Authentic civil society organisations should continue to monitor substitution attempts and react quickly to these.

\section{References}

Alternatyŭnaja maladziovaja platforma, 'Bielaruski Kamitet Moladziovych Arhanizacyj - miortvaja struktura' <http://ampby.org/2011/04/05/4385/> [accessed 28 December 2013]. 
Assembly of Pro-Democratic NGOs and Eastern Europe Studies Centre, 'Nongovernmental organisations: their role in the modern Belarusian society. Briefing note on the results of a national poll', 2010, Minsk.

Astapenia, Ryhor, 2012. 'Lukashenka's Youth', 22 September $<$ http://mfront. net/lukashenkas-youth.html> [accessed 14 November 2013].

Bian'ko, Nikolay, 2009. 'Suchestvuet li zakaz vlastei na izuchenie tret'ego sektora?', Nashe Mnenie.

Belarusian Republican Youth Union, BRSM, 'Molodezhnyi bilet - tvoja socialnaja zashchita!' <http://old.brsm.by/ru/news/stranici/table_ceni> [accessed 10 October 2013].

Cawson, Alan, 1985. Organised Interests and the State: Studies in MesoCorporatism, London: Sage Publication.

Centr Pravovoi Transformacii, "Ekspert Rolan Shovil": oficialnyi otchet Belarusi po UPO - ne vse chto interesyjet OON' < http://www.lawtrend.org/ru/ content/about/news/ofocialnii-otchet-belarusi-eto-ne-vse-chto-interesuet-oon/> [accessed 27 December 2013].

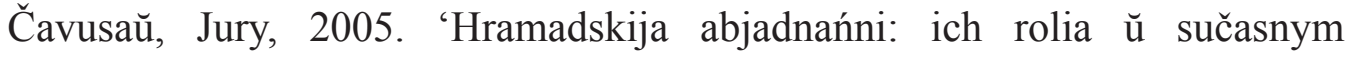
hramadstvie', Analityčnaja zapiska pa vynikach nacyjanalnacha sacyjalagičnacha apytańnia, Minsk, September.

— 2013. 'Registration of Belarusian NGOs abroad: functions and types of non-profit outsourcing', Belarus Info Letter, 4 (34).

Chernov, Viktor, 2009. 'Sovremennoe ponimanije grazhdanskogo obshestva (3)', Nashe Mnenie, 28 November.

— 2007. 'Tretiy sector v Belarusi: evoluciya, sovremennoe sostoyanie i perspektivi razvitia', Wider Europe Review, 4, 4 (14), pp. 1-18.

CIVICUS Civil Society Index, 2010. CIVICUS Statement on the Civil Society Index in Belarus, 12 November <http://civilsocietyindex.wordpress. com/2010/11/12/civicus-statement-on-the-civil-society-index-in-belarus/> [accessed 1 December 2013].

Clark, John, 1993. 'The Relationship between the State and the Voluntary Sector', The World Bank, October <http:/www-wds.worldbank.org/servlet/ WDSContentServer/WDSP/IB/1993/10/01/000009265_3961005082045/ Rendered/PDF/multi_page.pdf $>$.

Corry, Olaf, 2010. 'Defining and Theorizing the Third Sector', in Rupert Taylor (ed.), Third Sector Research, Springer Science Business Media. 
Dunaeva, Irina, 2011. 'Tretiy sector pod davleniem konsolidacii', Nashe Mnenie.

East European Study Centre, 2010. Analytical Review: Belarusian Challenge to the New EU Policy: Ignorance equals Legitimation, 2 (1).

Egorov, Andrei, 2011. 'Grazhdanskoe obshchestvo: analiz situacii i napravlenii reformirovaniia' in Hans-Georg Wiek, Stefan Malerius (ed.), Belarus i Evropeiskii Souz: ot izoliaii k sotrudnichestvu, Fond Konrada Adenauera, Vilnius, pp. 40-60.

—, 2010a. 'Politicheskaya situacija nakanune Vtorogo Foryma Grazhdanskogo Obshchestva' Centr evropeiskoi transformacii, November.

__, 2010b. 'Revansh v mittelshpitele: igri na pole Vostochnogo partnerstva', Centr evropeiskoi transformacii, October.

Forbrig, Joerg, 2004. 'Civil Society: Theory and Practice of East-Central Europe', European University Institute, April.

Foster, Kenneth W., 2001. 'Associations in the Embrace of an Authoritarian State: State Domination of Society?', Studies in Comparative International Development, 35, 4, pp. 84-109.

Frear, Matthew, 2006. 'Western Assistance to Civil Society in Belarus and Ukraine. What is it Good For?', Master Thesis, September.

Green, Andrew, 2002. 'Comparative Development of Post-Communist Civil Societies', Europe-Asia Studies, 54, 3, pp. 455-71.

Heurlin, Christopher, 2010. 'Governing Civil Society: The Political Logic of NGO-State Relations Under Dictatorship', Voluntas, 21, pp. 220-39.

Iliash, Igor', 2012. 'Gran', kotoraja sterlas', Belorusy i Rynok, 47 (1031), 1016 December $<$ http://tinyurl.com/qefcnw8> [accessed 2 December 2013].

Lenzi, Mark, 2002. 'Lost Civilization: The Thorough Repression of Civil Society in Belarus', Demokratizatsiya, 14, 4, pp. 401-22.

Matskevich, Vladimir, 2012. Obshestvennii dialog v Belarusi: ot narodovlastija k grazhdanskomy ychastiju, Minsk: Logvinov I.P.

Ministerstvo Obrazovaniya Respubliki Belarus', Respublikanskii reestr molodezhnikh i detskikh ob'edinenyi polzuchikhsia gosudarstvennoi podderzhkoi $<$ http://edu.gov.by/main.aspx?guid=1831 > [accessed 20 December 2013].

Narayan, Deepa, 1999. 'Bonds and Bridges: Social Capital and Poverty', World Bank < http://elibrary.worldbank.org/doi/pdf/10.1596/1813-9450-2167> [accessed 7 January 2014]. 
Novaya Evropa, 2009. 'Mozhet li konsyltativnyi sovet stat' obshchestvennym?', 17 July <http://n-europe.eu/tables/2009/07/17/mozhet_li_konsultativnyi_sovet_ stat_obshchestvennym $>$ [accessed 5 January 2014].

— 2010. 'OKS pri Administracii Prezidenta gotov predstavliat' Belarus' na Forume Grazhdanskogo Obshchestva' 29 September <http://n-europe.eu/ news/2010/09/29/oks_pri_administratsii_prezidenta_gotov_predstavlyat_ belarus_na_forume_grazhdanskogo $>$ [accessed 5 December 2013].

Novosti NISEPI, 2010. 'Monitoring obshchestvennogo mneniya v Belarusi', NISEPI, 2 (56).

Oficialnyj sait Minskoi gorodskoi organizacii 'Belorusskii respublikanskii soyuz molodezhi' <http://minsk-brsm.by/index.php?option=com content $\&$ view $=$ article $\&$ id $=61 \&$ catid $=9>$ [accessed 21 February 2014].

Polit.ru, 2009. 'Beloruskich stydentov zastavliajut platit' chlenskie vznosy v proprezidentskuju molodezhnuju organizaciju', 22 June $<$ http://polit.ru/ news/2009/06/22/chlen/> [accessed 20 February 2014].

Poslanie Prezidenta Respubliki Belarus Aleksandra Lukashenko k belorusskomu narodu i Parlamentu Respubliki Belarus, 16 April $2003<$ http://president.gov.by/ru/ news_ru/view/poslanie-prezidenta-respubliki-belarus-aleksandra-lukashenko-kbelorusskomu-narodu-i-parlamentu-respubliki-5822/> [accessed 2 January 2014].

Posner, Daniel, 2004. 'Civil Society and the Reconstruction of Failed States' in Robert A. Rotbig (ed.), When States Fail: Causes and Consequences, Princeton, New Jersey: Princeton University Press, pp. 237-55.

Pravoabaroncy za svabodnyja vybary, 2011. Doklad po rezultatam nezavisimogo nabludenija. Vybory Prezidenta Respubliki Belarus 19 dekabria 2010 goda, Minsk, 11 February <<http://belhelcom.org/sites/default/files/2011/Final_HRD_ monitoring_report_on_presidentialelection_in_Belarus_ru.pdf $>$ [accessed 28 December 2013].

Rovdo, Vladimir, 2004. 'Specifika i evolucija politicheskogo rezhima Respubliki Belarus', Acta Slavica Iaponica, 21, pp. 144-80.

Sadovskaya, Maria, 2006. 'Rade ne rady', Belorusy i Rynok, 6 (691), 1320 February <http://www.br.minsk.by/index.php?article=26744> [accessed 11 December 2013].

Schmitter, Philippe, 1974. 'Still the Century of Corporatism?', The Review of Politics, 36, 1, pp. 85-131.

Setianto, Benny D., 2007. 'Somewhere in Between: Conceptualizing Civil Society', The International Journal of Not-for-Profit Law, 10, 1, December. 
Shelest, Oksana, Vodolazhnskaya, Tatyana and Silitski, Vitali, 2010. 'Examination of results of research of Civil Society Index in Belarus'.

Shemyakin, Aleksandr, 'Pochemu Belaya Rus' ne stala partiei?, Analytical Belarusian Centre <http://abcby.info/ru/articles/24> [accessed 27 December 2013].

Shylo, Karina and Egorov, Andrei, 2013. 'Rol' i mesto grazhdanskogo obshchestva v sisteme donorskoi pomoshi ES dlia Belarusi', Rabochyi document Zentra evropeiskoi transformaci.

Sidarovič, Alena, 2007. 'Dziaržaŭna-hramadski sektar u bielaruskaj palityčnaj madeli', Palityčnaja Sfera, 7, pp. 75-81.

Silitski, Vitali, 2005. 'Preempting Democracy: The Case of Belarus', Journal of Democracy 16, 4 October, pp. 83-97.

—, 2009. 'Hramadski sektar ŭ Bielarusi - paŭsiadzionnaje žyćcio i arhanizacyjnaja pracesy’.

Eastern Partnership Civil Society Forum 2010, 26 October, Minsk <http://www. eap-csf.eu/assets/files/publications/NP_Zajavlenie_Oct10_eng.pdf $>$ [accessed 2 January 2014].

TUT.by, 2009a. 'Obshchestvenno-konsyltativnyi sovet pri Administracyi prezidenta provel pervoe zasedanie' <http://news.tut.by/politics/128616.html> [accessed 4 January 2013].

_ 2010. 'OKS pri administracyi prezidenta gotov predstavliat' Belarus' na forume grazhdanskogo obshchestva', 29 September <http://news.tut.by/ politics/198809.html> [accessed 3 December 2013].

UA Regnum, 2010. 'Ekzit-polly v Belarusi provedet organizacija obviniaemaja v falsifikacyi dannyx po Ukraine', 7 December $<$ http://www.regnum.ru/news/ polit/1354294.html> [accessed 4 January 2014].

Usov, Pavel, 2008. 'The Neo-Authoritarian Regime in the Republic of Belarus', Lithuanian Foreign Policy Review, 21, pp. 86-111.

Wu, Fengshi, 2003. 'Environmental GONGO Autonomy: Unintended Consequences of State Strategies in China', The Good Society, 12, 1, pp. 35-45.

Yakzhyk, Elena, 2009b. 'BRSM: "V nachych planach - polychat evropeiskoe finansirovanije",, Tut.by, 16 March < http://news.tut.by/society/131841.html> [accessed 23 October 2013].

Yurich, Aleksey, 2013. 'Andrei Egorov: Nelzya obvinyat Evrosouz v tom, chto v Belarusi ne proizochli izmeneniya', EuroBelarus, 31 October $<$ http://eurobelarus. 
info/news/policy/2013/10/31/andrey-egorov-nel-zya-obvinyat-evrosoyuz-v-tomchto-v-belarusi-ne-proizoshli-izmeneniya.html> [accessed 11 October 2013]

Zavtra tvojei strany, 2007. '1991-2006. Itogi ot Vladimira Rovdo', 14 May $2007<$ http://www.zautra.by/art.php?sn_nid=133\&sn_cat=9> [accessed 20 April 2014]

Annex 1: Table of the interviews with civil society experts and practitioners, 2013

\begin{tabular}{|c|c|c|}
\hline № & Name & Affiliation \\
\hline 1 & Taciana Paševalava & Consortium EuroBelarus \\
\hline 2 & Miraslaŭ Kobasa & NGO 'Leŭ Sapieha' \\
\hline 3 & Iryna Žychar & $\begin{array}{c}\text { Belarusian organisations of working } \\
\text { women }\end{array}$ \\
\hline 4 & Anna Herasimava & $\begin{array}{c}\text { The Barys Zvozskau Belarusian } \\
\text { Human Rights House }\end{array}$ \\
\hline 5 & Andrei Egorov & Centre for European Transformation \\
\hline 6 & Jury Čavusaŭ & Assembly of Pro-Democratic NGOs \\
\hline 7 & Jaraslaŭ Bekiš & Association 'Green Network' \\
\hline
\end{tabular}

